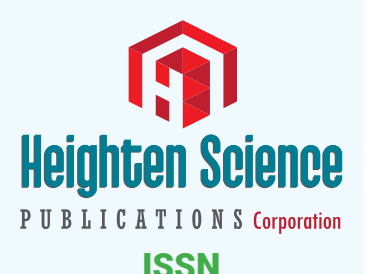

ISSN

2640-2823

\title{
Evaluation of the effects of Leech Salivary Extract (LSE) on Haematological parameters in Rats
}

\author{
Hausatu Babayi ${ }^{1 *}$, Ojo Olufunmilola Praise ${ }^{1}$, Labake Fadipe \\ Ajoke $^{2}$, Israel Kayode Olayemi ${ }^{3}$, Elisha $\mathrm{Baba}^{4}$ and Oladosun \\ Oluwale Peter ${ }^{5}$ \\ 'Department of Microbiology, Federal University of Technology, Minna, Nigeria \\ 2Department of Chemistry, Federal University of Technology, Minna, Nigeria \\ ${ }^{3}$ Department of Biological Sciences, Federal University of Technology, Minna, Nigeria \\ ${ }^{4}$ Clinic, National Institute for Pharmaceutical Research Development, Idu-Abuja, Nigeria \\ ${ }^{5}$ Department of Microbiology, National Institute for Pharmaceutical Research Development, \\ Idu-Abuja, Nigeria
}

\begin{abstract}
*Address for Correspondence: Hausatu Babayi, Department of Microbiology, Federal University of Technology, Minna, Nigeria, Tel: +2348033700406;

Email: acadbabayi@yahoo.com
\end{abstract}

Submitted: 09 January 2018

Approved: 18 January 2018

Published: 19 January 2018

Copyright: @ 2018 Babayi H, et al. This is an open access article distributed under the Creative Commons Attribution License, which permits unrestricted use, distribution, and reproduction in any medium, provided the original work is properly cited

Keywords: Blood metabolites; Leech Salivary Extract; Relative organ weight; Sub-chronic toxicity; Wister rats

Check for updates

\section{Abstract}

The effects of Leech Salivary Extract (LSE) on some haematological, immunological and organ weight parameters in rats, during a twenty eight days oral administration of 25,50 and $100 \mathrm{mg} / \mathrm{kg}$ body weight doses, was investigated. $\mathrm{LD}_{50}$ and sub chronic toxicity was determined using standard methods. The oral $\mathrm{LD}_{50}$ was above $5000 \mathrm{mg} / \mathrm{kgbw}$. Oral administration of LSE $(25 \mathrm{mg} / \mathrm{kgbw}, 50 \mathrm{mg} / \mathrm{kgbw}, 100 \mathrm{mg} / \mathrm{kgbw})$ for 28 days had no significant $(p>0.05)$ effect on the differential white blood cells (lymphocytes, monocytes, basophils, neutrophils, eosinophils), red blood cell indices (RBC count, PCV, $\mathrm{HB}$, platelets, $\mathrm{MCHC}$ and $\mathrm{MCH}$ ), feed intake, body weight gain and relative organ weight of lung, heart, liver, kidney, spleen and stomach of rats. However, the LSE evoked a significant $(p>0.05)$ increase in the level of MCV in treated rats compared to the control. These results, indicating low toxicity and no negative significant effects of LSE on haemato-immunological indices in rats, suggest that the extract is safe for development and use as therapeutic for managing clinical conditions.

\section{Introduction}

The studies of haematological parameters are of ecological and physiological interest that helps to understand the characteristics of blood in relation to the environment (Obel et al., 2016). The assessments of haematological and differential parameters reveal the effects of foreign compounds in blood constituents in living system. The evaluation of these parameters: Red blood cells (erythrocytes), White blood cells (leucocytes) and platelets (thrombocytes) give the avenue to investigate the presence of several constituents in the blood of animals which play important roles in nutritional, pathological and physiological status of animals [1]. Packed cell volume (PCV) is the percentage of red blood cells (RBC) in the blood circulated around the body. It is a point of reference of the capability of RBCs to deliver oxygen to tissues. Reference range for PCV is 34-57\% [2]. Mean Corpuscular Hemoglobin (MCH), Mean Corpuscular Volume (MCV) and Mean Corpuscular Hemoglobin Concentration (MCHC) are haematological parameters which are related to individual RBC. MCV reflects the average size of RBC while $\mathrm{MCH}$ reflects the average weight of haemoglobin (HB) content of RBC and MCHC reflects the average concentration of haemoglobin content of the RBC. Haemoglobin on the other hand measures the total amount of the oxygen carrying protein in the blood which generally reflects the number of RBC in the blood. Platelets are determinants of blood viscosity which correlates positively to blood pressure. Basophils are the least 
common granulocytes known to contain histamine and heparin which promote blood flow to tissues and prevent rapid blood clotting. Basophils possess protein receptors on their cell surface that can bind IgE, an immunoglobulin involved in allergy and macro parasite defence [3]. Thus, high levels will trigger allergic reactions while low levels are normal. Eosinophils, on the other hand, protect the body against allergic reaction as well as parasitic infections. Therefore, low eosinophil count is accepted as normal and high levels suggests allergy. Lymphocytes and neutrophils are the major indices of immunity. Elevated levels is an indication of a boost in immunological activity as a result of infection, a low level may indicate impaired immune system [3].

Medical application of leeches dates back to the beginning of civilization [4]. Traditionally, leech has been used for bloodletting, skin diseases, nervous system abnormalities, urinary and reproductive system disorder, ocular inflammation, dental problems and haemorrhoids [5,6]. This research aimed at evaluating the effect leech salivary extract on haematological parameters in rats.

\section{Materials and Methods}

\section{Collection and storage of leeches}

Leeches were collected from a stream in a natural dam site in Panda Development Area, Karu Local Government Area, Nassarawa State, Nigeria between September, 2014 and January, 2015. The Leeches were identified as Hirudo medicinalis by a Zoologist in the Department of Biological Sciences, Federal University of Technology Minna, Nigeria. The leeches were kept and maintained in well-aerated plastic containers filled with non-chlorinated water (borehole water) and kept at room temperature $\left(25 \pm 2^{\circ} \mathrm{C}\right)$ throughout the period of study. Water was also changed every three days. They were kept under $12 \mathrm{~h}: 12 \mathrm{~h}$ light and dark cycle at room temperature $\left(25 \pm 2^{\circ} \mathrm{C}\right)$. Leeches were fed with cow blood at intervals of three weeks [7].

\section{Extraction of leech saliva}

Leech salivary extract (LSE) was collected without sacrificing the animal as described by Abdulkader et al., 2011). Starved leeches were transferred into a closed glass test tube immersed in an ice container. The set-up was then allowed to stand for 15 - 20 minutes. The leeches at this point were completely paralyzed and forced to regurgitate their intestinal content that appeared a colourless, foamy salivary fluis. The salivary extract was then aspirated using a sterile hypodermic needle and syringe and then transferred into a sterile container. Bloody salivary extract was discarded. The extract was then stored at $-4^{\circ} \mathrm{C}$.

\section{Experimental animals}

Thirty healthy Wister rats (Rattus novergicus) weighing an average of $170 \mathrm{~g}$ were used in this study. The animals were obtained from the Animal House, Department of Biochemistry, Faculty of Natural Sciences, Ibrahim Badamasi Babangida University Lapai, and Nigeria. They were housed in stainless steel cages bedded with dried clean wood shavings, maintained at a temperature of $25 \pm 2^{\circ} \mathrm{C}$ and observed under 12-hour light/dark cycle, in a well-ventilated room, for 2 weeks before the commencement of the experiment. They were fed with standard animal feeds (Bendel feeds and flour mills, Edo State, Nigeria) and tap water ad libitum. The cages were cleaned and disinfected every two days. Soiled wood shavings were replaced often. The feed, water containers were washed regularly. The animals were housed and cared for in accordance with Good Laboratory Practice (GLP) regulations of WHO (1998). The principles of Laboratory Animal Care [8], were also followed throughout the study.

\section{Experimental design}

The rats were randomly assigned into six groups with each group having five rats. The groups were designated as 1-6. Group 1 was the Control group and received 
normal tap water, Groups 2, 3 and 4 were administered 25, 50 and $100 \mathrm{mg} / \mathrm{kgbw}$ LSE, respectively. Groups 5 and 6 were administered Jobelyn $(4.17 \mathrm{mg} / \mathrm{kgbw})$ and Dexamethasone $(3 \mathrm{mg} / \mathrm{kgbw})$, respectively. The administration was done orally with the aid of an oropharyngeal cannula for 28 days. Each rat was marked at specific points on the body to distinguish it from the others. The volume of LSE to be administered according to the weight of the rat was calculated using the formula:

$$
\text { Volume }(\mathrm{ml})=\frac{\text { Weight of animal }(\mathrm{g}) \times \text { Dose to administer }(\mathrm{mg})}{\text { Concentration }(\mathrm{mg} / \mathrm{ml}) \times 1000 \mathrm{~g}[9]}
$$

\section{Acute toxicity studies $\left(\mathrm{LD}_{50}\right)$ of leech salivary extracts}

The method of Aniagu et al. [10], was employed in the acute toxicology studies $\left(\mathrm{LD}_{50}\right)$ of LSE. Healthy Wister rats were used for this study. The rats were fasted for 12 hours before the administration of the LSE. The rats were weighed before administration of the extract. The acute toxicity study was conducted to observe the range of toxicity so the proper dose level could be established. The study was conducted in two phases. In the first phase, nine rats were divided into 3 groups of 3 rats each. Group 1, 2 and 3 animals were administered with $10 \mathrm{mg} / \mathrm{kgbw}, 100 \mathrm{mg} / \mathrm{kgbw}$ and $1000 \mathrm{mg} / \mathrm{kg}$ body weight of LSE, respectively, to possibly establish the range of dose producing toxic effect. In the second phase, the experiment was set up as the first phase of three groups with 1 rat per group. Groups 1, 2 and 3 animals were administered with $1600 \mathrm{mg} /$ kgbw, $2900 \mathrm{mg} / \mathrm{kgbw}$ and $5000 \mathrm{mg} / \mathrm{kgbw}$ of the LSE, respectively. Administration of the LSE was done orally with the use of oral cannula. The weights of the rats were taken again one week after administration of the LSE.

\section{Weekly body weight and relative organ weight}

The body weights of the rats were taken weekly in the course of the experiment and after the experiment. The weight gains were computed as follows:

Weight gain= Final weight of rat (g)-Initial weight of rat (g)

The relative organ weight (ROW) was calculated as follows:

$$
\text { ROW }=\frac{\text { Weight of animal }(\mathrm{g}) \times \text { Dose to administer }(\mathrm{mg})}{\text { Body Weight of Rat on Sacrifice Day }(\mathrm{kg})} 100
$$

\section{Collection of blood samples}

The collection of blood was done as described by Shittu et al. [11]. At the end of the 28days treatment, the animals were starved overnight but still had water ad libitum before they were sacrificed under diethyl ether anaesthesia. The whole blood was collected in heparin bottles.

\section{Determination of haematological parameters}

The haematological components including haemoglobin (Hb), packed cell volume (PCV), red blood cells (RBC), mean corpuscular volume (MCV), mean corpuscular haemoglobin $(\mathrm{MCH})$, mean corpuscular haemoglobin concentration (MCHC), white blood cells (WBC), lymphocytes, platelet and differential counts (neutrophils, eosinophils, basophils and lymohocytes) were determined using standard methods [11].

\section{Statistical Analysis}

Results were expressed as mean value \pm standard error mean (SEM). Among groups, comparisons of means were performed by the Analysis of Variance (ANOVA) test, for statistical significance of differences, at $p=0.05$. The means were subsequently separated using Duncan Multiple Range Test (DMRT. All data analysis were done using the statistical package SPSS version 19.0. 


\section{Results}

\section{Acute oral toxicity of leech salivary extract}

There was no death recorded in the animals that received LSE from $10 \mathrm{mg} / \mathrm{kgbw}$ to $5000 \mathrm{mg} / \mathrm{kgbw}$ (Table 1). Furthermore, the animals did not show any change in general behavior and other physiological activities such as dizziness, aggressiveness, tachypnoea (abnormal rapid breathing), or convulsion. From the above toxicity studies, $\mathrm{LD}_{50}$ of the LSE is estimated to be greater than $5000 \mathrm{mg} / \mathrm{kgbw}$ in rats.

\section{Effect of leech salivary extract on body weight gain of the rats}

As shown in table 2, there was an insignificant $(p>0.05)$ increase in the initial and final weights of the rats in all treated groups when compared with the Control. The rats gained significant $(\mathrm{p}<0.05)$ weight across the groups after 28days of LSE as well as dexamethasone and jobelyn administration though, weight gain observed in groups administered 50mg/kgbw LSE and dexamethasone were similar but low when compared with the other groups and Control.

\section{Feed intake of rats fed with leech salivary extract over 28 days study period}

The daily feed intake of the rats following oral administration of LSE is presented in table 3. There was no significant ( $p>0.05$ ) difference in the daily feed intake between the treated groups and the Control in the first week of treatment. However, there were significant $(\mathrm{p}<0.05)$ increases in feed intake in the groups treated with $100 \mathrm{mg} / \mathrm{kgbw}$ LSE and dexamethasone when compared with control. In the $3^{\text {rd }}$ week, however, there was a significant $(p>0.05)$ reduction in feed intake of rats that received $50 \mathrm{mg} / \mathrm{kgbw} \mathrm{LSE}$,

Table 1: Acute Oral Toxicity Profile of Leech Salivary Extract in Rats.

\begin{tabular}{|c|c|c|}
\hline Group & Dosage $(\mathbf{m g} / \mathbf{k g b w})$ & Mortality/No of rats \\
\hline 1 & 100 & $0 / 3$ \\
\hline 2 & 500 & $0 / 3$ \\
\hline 3 & 1000 & $0 / 3$ \\
\hline 4 & 1600 & $0 / 3$ \\
\hline 5 & 2900 & $0 / 3$ \\
\hline 6 & 5000 & $0 / 3$ \\
\hline mg/kgbw: Milligram per kilogram per body weight.
\end{tabular}

Table 2: Effect of Leech Salivary Extract on Body Weight Gain of Rats.

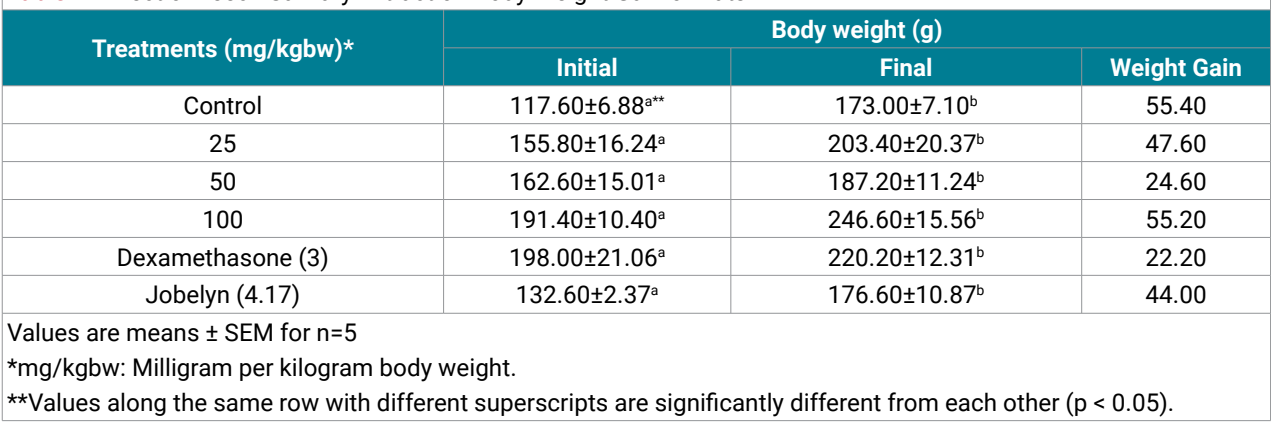

Table 3: Daily Feed Intake by Rats Following Oral Administration of Leech Salivary Extract.

\begin{tabular}{|c|c|c|c|c|}
\hline \multirow{2}{*}{ Treatments (mg/kgbw)* } & \multicolumn{4}{|c|}{ Feed Intake (g) } \\
\hline & Week 1 & Week 2 & Week 3 & Week 4 \\
\hline Control & $63.42 \pm 0.56^{\mathrm{a}^{\star \star}}$ & $68.71 \pm 0.80^{\mathrm{a}}$ & $70.42 \pm 2.47^{b}$ & $71.42 \pm 0.86^{b}$ \\
\hline 25 & $67.14 \pm 2.10^{\mathrm{a}}$ & $67.43 \pm 2.31^{\mathrm{a}}$ & $66.14 \pm 3.21^{\mathrm{b}}$ & $73.42 \pm 2.33^{b}$ \\
\hline 50 & $58.57 \pm 0.61^{a}$ & $58.14 \pm 2.31^{a}$ & $58.57 \pm 3.27^{a}$ & $61.85 \pm 1.66^{b}$ \\
\hline 100 & $73.00 \pm 3.53^{a}$ & $83.85 \pm 0.91^{b}$ & $83.14 \pm 1.45^{c}$ & $74.57 \pm 0.81^{b}$ \\
\hline Dexamethasone (3.0) & $79.00 \pm 4.92^{\mathrm{a}}$ & $76.71 \pm 0.71^{b}$ & $75.57 \pm 3.74^{b}$ & $55.28 \pm 2.79^{a}$ \\
\hline Jobelyn (4.17) & $58.28 \pm 0.68^{a}$ & $57.85 \pm 0.79^{a}$ & $64.71 \pm 1.72^{\mathrm{b}}$ & $65.85 \pm 1.22^{\mathrm{b}}$ \\
\hline $\begin{array}{l}\text { Values are means } \pm \text { SEM for } n= \\
{ }^{*} \mathrm{mg} / \mathrm{kgbw} \text { : Milligram per kilogr } \\
\star \star \text { Values along the same colun }\end{array}$ & $\begin{array}{l}\text { veight. } \\
\text { ferent supers }\end{array}$ & e significan & t from eac & $(p<0.05)$ \\
\hline
\end{tabular}


from $70.42 \pm 2.47$ to $58.57 \pm 3.27$ and a significant $(p>0.05)$ increase from $70.42 \pm 2.47$ t0 $83.14 \pm 1.45$ in rats that received $100 \mathrm{mg} / \mathrm{kgbw}$ LSE. In the $4^{\text {th }}$ week, the groups of rats that received $25 \mathrm{mg} / \mathrm{kgbw}$ and $100 \mathrm{mg} / \mathrm{kgbw}$ had an insignificant $(\mathrm{p}>0.05)$ increase in feed intake while groups treated with $50 \mathrm{mg} / \mathrm{kgbw}$ and jobelyn had an insignificant $(p>0.05)$ decrease in feed intake. Groups treated with dexamethasone had a significant $(p<0.05)$ decrease in feed intake when compared with control and other treatment groups.

\section{Relative organ weight of rats after oral administration of leech salivary extract}

The computed liver, kidney, spleen, lungs, heart and stomach body weight ratios of the rats, as represented in table 4 , were not significantly $(\mathrm{p}>0.05)$ different across the LSE treatment groups, as well as, dexamethasone and jobelyn with respect to the Control. However, the group that received dexamethasone had a significant $(p<0.05)$ reduction in the relative organ weight of the lungs when compared with the Control.

\section{Effect of leech salivary extract on hematograms of rats}

Table 5 illustrates the changes in haematological indices in rats, following chronic administration of LSE $(25 \mathrm{mg} / \mathrm{kgbw}, 50 \mathrm{mg} / \mathrm{kgbw}$ and $100 \mathrm{mg} / \mathrm{kg})$. All the doses of LSE and jobelyn and dexamethasone administered did not significantly $(\mathrm{P}>0.05)$ affect the levels of PCV, HB, platelets and MCHC in the rats. There was an insignificant ( $p>0.05$ ) decrease in the WBC count in groups treated with LSE as well as dexamethasone but a significant $(p<0.05)$ increase in the group treated with jobelyn compared with the Control. Also, at $25 \mathrm{mg} / \mathrm{kgbw}$ and $50 \mathrm{mg} / \mathrm{kgbw}$ LSE, there was a significant $(\mathrm{p}<0.05)$ reduction in the RBC count of the rats. At $100 \mathrm{mg} / \mathrm{kgbw}$ LSE, there was an insignificant ( $>0.05$ ) reduction in RBC count while in the dexamethasone and jobelyn groups, there was an insignificant ( $p>0.05$ ) increase in RBC when compared with the Control but significantly higher than those of the LSE treated rats. However, while there was an insignificant ( $p>0.05$ ) increase in the MCV level of the rats at $25 \mathrm{mg} / \mathrm{kgbw}$ and $100 \mathrm{mg} /$ kgbw LSE as well as dexamethasone, a significant $(\mathrm{p}<0.05)$ increase in rats administered $50 \mathrm{mg} / \mathrm{kgbw}$ LSE and a significant $(\mathrm{p}<0.05)$ decrease in jobelyn group were recorded when compared with their respective Control. Finally, there was a non-significant

\begin{tabular}{|c|c|c|c|c|c|c|}
\hline Treatment s (mg/kgbw)* & Liver & Kidney & Lungs & Heart & Spleen & Stomach \\
\hline Control & $3.08 \pm 0.14^{\mathrm{a}^{\star \star}}$ & $0.61 \pm 0.03^{a}$ & $0.82 \pm 0.03^{b}$ & $0.41 \pm 0.03^{a}$ & $0.42 \pm 0.04^{a}$ & $1.62 \pm 0.11^{\mathrm{a}}$ \\
\hline 25 & $3.03 \pm .092^{\mathrm{a}}$ & $0.57 \pm 0.01^{\mathrm{a}}$ & $0.78 \pm 0.06^{b}$ & $0.39 \pm 0.02^{\mathrm{a}}$ & $0.37 \pm 0.09^{a}$ & $1.70 \pm 0.05^{\mathrm{a}}$ \\
\hline 50 & $3.38 \pm .020^{\mathrm{a}}$ & $0.66 \pm 0.02^{\mathrm{a}}$ & $0.80 \pm 0.07^{b}$ & $0.41 \pm 0.01^{\mathrm{a}}$ & $0.47 \pm 0.44^{a}$ & $1.33 \pm 0.10^{\mathrm{a}}$ \\
\hline 100 & $3.06 \pm 0.11^{\mathrm{a}}$ & $0.63 \pm 0.03^{a}$ & $0.74 \pm 0.05^{b}$ & $0.38 \pm 0.03^{\mathrm{a}}$ & $0.35 \pm 0.04^{\mathrm{a}}$ & $1.39 \pm 0.10^{\mathrm{a}}$ \\
\hline Dexamethasone (3) & $2.92 \pm 0.21^{\mathrm{a}}$ & $0.67 \pm 0.04^{\mathrm{a}}$ & $0.59 \pm 0.02^{\mathrm{a}}$ & $0.36 \pm 0.02^{\mathrm{a}}$ & $0.32 \pm 0.07^{a}$ & $1.76 \pm 0.10^{\mathrm{a}}$ \\
\hline Jobelyn(4.17) & $3.17 \pm 0.08^{a}$ & $0.58 \pm 0.02^{\mathrm{a}}$ & $0.73 \pm 0.07^{b}$ & $0.39 \pm 0.01^{\mathrm{a}}$ & $0.39 \pm 0.03^{\mathrm{a}}$ & $1.73 \pm 0.09^{a}$ \\
\hline \multicolumn{7}{|c|}{$\begin{array}{l}\text { Values are means } \pm \text { SEM for } n=5 \\
{ }^{*} \mathrm{mg} / \mathrm{kgbw} \text { : Milligram per kilogram body weight. } \\
\star \star \text { Values along the same column with different } s\end{array}$} \\
\hline
\end{tabular}

Table 5: Effects of Leech Salivary Extract on Hematograms of Rats.

\begin{tabular}{|c|c|c|c|c|c|c|c|c|}
\hline Treatments (mg/kgbw) & $\begin{array}{l}\text { PCV } \\
(\%)\end{array}$ & $\begin{array}{c}\mathrm{HB} \\
(\mathrm{g} / \mathrm{dL})\end{array}$ & $\begin{array}{c}\text { WBC } \\
\left(\times 10^{9}\right)\end{array}$ & $\begin{array}{c}\text { RBC } \\
\left(\times 10^{9}\right)\end{array}$ & $\begin{array}{l}\text { Platelets } \\
\left(x 10^{6}\right)\end{array}$ & $\begin{array}{c}\text { MCV } \\
\text { (FL) }\end{array}$ & $\begin{array}{c}\text { MCH } \\
(\mathrm{pg})\end{array}$ & $\begin{array}{l}\text { MCHC } \\
(\mathrm{g} / \mathrm{dL})\end{array}$ \\
\hline Control & $46.20 \pm 1.24^{\mathrm{a}^{*}}$ & $15.40 \pm 0.42^{\mathrm{a}}$ & $4.98 \pm 0.23^{\mathrm{a}}$ & $5.02 \pm 0.38^{b}$ & $319.40 \pm 10.90^{\mathrm{a}}$ & $96.80 \pm 3.18 a^{b}$ & $31.20 \pm 1.74^{\mathrm{ab}}$ & $32.32 \pm 0.81^{a}$ \\
\hline 25 & $47.00 \pm 0.94^{\mathrm{a}}$ & $15.68 \pm 0.32^{\mathrm{a}}$ & $4.46 \pm 0.26^{\mathrm{a}}$ & $4.44 \pm 0.25^{\mathrm{a}}$ & $327.20 \pm 4.23^{\mathrm{a}}$ & $107.60 \pm 7.60^{\mathrm{b}}$ & $35.60 \pm 2.50^{\mathrm{ab}}$ & $32.04 \pm 1.18^{a}$ \\
\hline 50 & $49.60 \pm 2.48^{a}$ & $16.52 \pm 0.82^{a}$ & $4.90 \pm 0.26^{\mathrm{a}}$ & $4.14 \pm 0.19^{\mathrm{a}}$ & $325.00 \pm 8.20^{\mathrm{a}}$ & $122.00 \pm 11.7^{c}$ & $40.40 \pm 3.700^{b}$ & $33.24 \pm 0.06^{\mathrm{a}}$ \\
\hline 100 & $51.00 \pm 1.48^{\mathrm{a}}$ & $17.00 \pm 0.34^{\mathrm{a}}$ & $4.82 \pm 0.37^{\mathrm{a}}$ & $4.66 \pm 0.23^{\mathrm{ab}}$ & $315.60 \pm 19.66^{\mathrm{a}}$ & $111.00 \pm 7.81^{\mathrm{b}}$ & $37.00 \pm 2.64^{\mathrm{ab}}$ & $33.32 \pm 0.06^{\mathrm{a}}$ \\
\hline Dexamethasone (3) & $52.00 \pm 2.00^{\mathrm{a}}$ & $17.32 \pm 0.65^{a}$ & $4.60 \pm 0.23^{\mathrm{a}}$ & $5.16 \pm 0.30^{\mathrm{b}}$ & $320.20 \pm 2.80^{\mathrm{a}}$ & $101.60 \pm 2.83^{b}$ & $33.60 \pm 1.07^{\mathrm{ab}}$ & $33.22 \pm 0.02^{\mathrm{a}}$ \\
\hline Jobelyn (4.17) & $45.00 \pm 1.58^{\mathrm{a}}$ & $15.00 \pm 0.53^{\mathrm{a}}$ & $5.72 \pm 0.33^{b}$ & $5.22 \pm 0.28^{b}$ & $327.40 \pm 4.05^{\mathrm{a}}$ & $81.80 \pm 4.52^{\mathrm{a}}$ & $27.20 \pm 1.49^{a}$ & $33.54 \pm 0.35^{\mathrm{a}}$ \\
\hline
\end{tabular}

Values are means \pm SEM for $n=5$

*Values along the same column with different superscripts are significantly different from each other $(p<0.05)$.

PCV: Packed Cell Volume; MCV: Mean Corpuscular Volume; g/dL: gram per deciliter; HB: Hemoglobin count; MCH: Mean Corpuscular Hemoglobin; FL: Femtoliter; WBC: White Blood Cell count; MCHC: Mean Corpuscular Hemoglobin Concentration; pg: picograms; RBC: Red Blood Cell count; mg/kgbw: Milligram per kilogram body weight 
(p>0.05) increase of MCH in the groups treated with LSE as well as dexamethasone and a non-significant $(p>0.05)$ decrease in jobelyn group when compared with their respective Control. However, $\mathrm{MCH}$ in rats treated with $50 \mathrm{mg} / \mathrm{kgbw}$ LSE $(40.4 \pm 3.70 \mathrm{pg})$ was significantly higher in the group administered Jobelyn $(27.20 \pm 1.49 \mathrm{pg})$

\section{Effect of leech salivary extract on differential count of rats}

Table 6 illustrates the changes in differential counts of rats following chronic administration of LSE. The groups treated with LSE, as well as, jobelyn and dexamethasone had an insignificant $(p>0.05)$ decrease in the neutrophil count, but insignificant ( $>0.05)$ increase in the lymphocyte count. There was an insignificant decrease in the monocyte count in all treatment groups when compared with their respective control. There was an insignificant $(p>0.05)$ increase in eosinophil count for groups administered $25 \mathrm{mg} / \mathrm{kgbw}$ LSE and dexamethasone. Also, for the groups administered $50 \mathrm{mg} / \mathrm{kgbw}$ and $100 \mathrm{mg} / \mathrm{kgbw}$ LSE as well as jobelyn, the eosinophil count decreased insignificantly when compared with their respective control. The basophil counts of the LSE treated groups as well as dexamethasone and jobelyn were not significantly ( $p>0.05$ ) different when compared with the Control group rats.

\section{Discussion}

The median lethal dose $\left(\mathrm{LD}_{50}\right)$ is measured as the relative response of an experimental animal exposed to a test substance [12]. It is a standard measurement of acute toxicity stated in milligrams ( $\mathrm{mg}$ ) of the test substance, per kilogram $(\mathrm{kg})$ of body weight of experimental animal. The value of $\mathrm{LD}_{50}$ for a test substance is the dose required to kill half the number of a tested population after a specific test duration [13]. The results obtained from the present study showed that LSE did not cause rat mortality or other signs of toxicity even at a dose limit of $5000 \mathrm{mg} / \mathrm{kgbw}$. This result is in agreement with the reports of Kabiru et al. [14], and Atsafack et al. [15], that revealed that methanolic leaf extract of Eucalyptus camaldulensis exhibited $\mathrm{LD}_{50}$ above $5000 \mathrm{mg} / \mathrm{kgbw}$ and was, therefore, considered non-toxic acutely.

Changes in body weight of an animal serve as a sensitive indication of the general health status of the animal and also one of the first critical signs of toxicity [16]. Increase in body weight may be presumed as normal while decreased body weight is seen as a sign of ill health. It was observed in this present study that the mean body weight of the animals in all experimental groups increased insignificantly when compared with the control. The weight gain observed may be an indication that the extract did not hamper the growth of the animals as reported by Ezeja et al. [17], in the acute and sub-acute toxicity profile of methanol leaf extract of Gouania longipetala in rats.

In toxicological studies, an important requirement is the ability to assess the effects of chemical compounds on specific organs. Therefore, the analysis of organ weight is an integral component in the assessment of these compounds for their potential harmful effects on organs [18] (Sellers et al., 2007). Organ weight can be the most sensitive indicator of an effect exerted by an experimental substance on the experimental

\begin{tabular}{|c|c|c|c|c|c|}
\hline \multirow{2}{*}{ Treatments $(\mathrm{mg} / \mathrm{kgbw})^{*}$} & \multicolumn{3}{|c|}{ Differential leukocyte (\%) } & \multirow[b]{2}{*}{ Eosinophil } & \multirow[b]{2}{*}{ Basophil } \\
\hline & Neutrophil & Lymphocyte & Monocyte & & \\
\hline Control & $49.20 \pm 3.24^{\mathrm{a}^{\star \star}}$ & $42.00 \pm 3.33^{\mathrm{a}}$ & $5.20 \pm 0.96^{\mathrm{a}}$ & $3.00 \pm 0.31^{\mathrm{a}}$ & $0.20 \pm 0.20^{\mathrm{a}}$ \\
\hline 25 & $47.60 \pm 3.74^{\mathrm{a}}$ & $44.60 \pm 3.12^{\mathrm{a}}$ & $4.00 \pm 0.94^{\mathrm{a}}$ & $3.40 \pm 0.67^{a}$ & $0.20 \pm 0.20^{\mathrm{a}}$ \\
\hline 50 & $48.40 \pm 2.63^{a}$ & $45.40 \pm 3.68^{a}$ & $3.60 \pm 0.67^{a}$ & $2.60 \pm 0.67^{a}$ & $0.00 \pm 0.00^{\mathrm{a}}$ \\
\hline 100 & $44.00 \pm 4.32^{\mathrm{a}}$ & $50.20 \pm 4.44^{\mathrm{a}}$ & $3.20 \pm 0.37^{a}$ & $2.60 \pm 0.40^{\mathrm{a}}$ & $0.00 \pm 0.00^{a}$ \\
\hline Dexamethasone (3) & $47.40 \pm 2.48^{a}$ & $44.60 \pm 1.91^{\mathrm{a}}$ & $4.60 \pm 0.66^{\mathrm{a}}$ & $3.400 \pm 0.56^{\mathrm{a}}$ & $0.00 \pm 0.00^{\mathrm{a}}$ \\
\hline Jobelyn (4.17) & $47.80 \pm 1.93^{\mathrm{a}}$ & $45.60 \pm 1.69^{a}$ & $4.00 \pm 0.31^{\mathrm{a}}$ & $2.80 \pm 0.96^{a}$ & $0.20 \pm 0.20^{\mathrm{a}}$ \\
\hline
\end{tabular}


animal, as the substance may have delirious effects on the animal without showing any morphological changes [19]. According to Albert et al. [20], a variation in relative organ weight of an animal is a major index of toxicity. Result of the relative organ weight obtained from the present study showed that there was no significant $(p>0.05)$ difference in the relative weights of kidney, heart, liver, lung, spleen and stomach of rats administered LSE when compared with the Control. This observation corroborates the findings of Enechi and Ozougwu [21], who reported insignificant change in the liver weight of rats administered ethanol leaf extract of Mucuna pruriens and deduced that the extract did not exert any gross pathological effect on the liver of the rats.

An increased PCV value means abnormal increase in RBC production while a low level of PCV depicts loss of RBC as a result of blood loss and/or failure of bone marrow production. In this study, the LSE did not interfere with the level of PCV of the animals since there was no significant difference between the test groups and Control. Since PCV level is indicative of oxygen uptake and transfer to tissues, the steady insignificant increase in PCV values in this study showed that the extract did not have any effect on the PCV count of the rats. This is in accordance with the report of Olatunji et al. [22], who stated that administration of aqueous extract of Hibiscus sabdariffa calyx showed no significant difference on haematocrit (PCV) count of treated rats.

However the observed reduction in RBC level in rats administered with $25 \mathrm{mg}$ / kgbw and $50 \mathrm{mg} / \mathrm{kgbw}$ LSE should be taken with caution. This reduction could be due to the prolonged administration of the extract which may allow the extract to gradually manifest its adverse effect on the bone marrow of the groups of rats for that duration. The effect was observed by Olatunji et al. [22], in consumption of aqueous extract of Hibiscus sabdariffa for a long time which led to some level of anaemia despite its beneficial characteristics. Furthermore, at $100 \mathrm{mg} / \mathrm{kgbw}$ LSE, dexamethasone and jobelyn, there was no significant effect exerted by the extract on RBC count. Therefore, the extract did not exhibit any toxic effect on oxygen uptake and transfer to the tissues of the rats at this concentration. The extract may contain elements that are capable of reducing the $\mathrm{RBC}$ count at low concentrations while stabilizing it at high concentration.

The white blood cell (WBC) count following administration of LSE, could be indicative of its ability to boost the immune system of the rats against invaders [23]. Since there was no significant difference in WBC count across all groups except jobelyn, it can be presumed that the production of WBC was constant in all treated groups but increased in the groups administered with jobelyn (being an immune stimulant). The stability of WBC count across LSE treated groups suggests the inability of the extract to produce any toxic effect that may interfere with the immune mechanism of the rats. Mbajiorgu et al. [24], observed elevated WBC count in rats fed low protein diets.

The results of the present study have shown that administration of LSE for 28days did not cause any significant toxic effect on the haemoglobin concentration, platelet count, $\mathrm{MCH}$ and MCHC. This means that neither the incorporation of haemoglobin into red blood cells nor the morphology and osmotic fragility of the red blood cells were altered as reported by Adebayo et al. [25], who observed that yoyo bitters did not exert any toxic effect on some of the haematological parameters in Wister rats.

Indices of white blood cells, i.e., the differential leucocytes, are the principal haematological parameters which confers immunity. They defend the body against foreign proteins. Results from this study showed that there was no significant alteration in the differential counts of the LSE treated animals compared with the Control. This suggests that the consumption of LSE did not induce toxic effects that may trigger immune response or allergy in the rats. Similar observation was made in previous reports of Sani et al. [26], in which prolonged administration of aqueous stem extract of Anisopus mannii at graded doses did not significantly affect the values of $\mathrm{Hb}$ and $\mathrm{WBC}$ when compared with their respective day zero values. 


\section{Conclusion}

Oral $\mathrm{LD}_{50}$ of LSE is above $5000 \mathrm{mg} / \mathrm{kgbw}$. Oral administration of LSE for 28 days did not cause significant variation in the red blood cell indices (PCV, MCH, MCHC, MCV, and HB), white blood cell and differential counts (basophils, neutrophils, eosinophils and monocytes and lymphocytes). It, also, increased the feed intake as treatment progressed leading to increased body weight in the rats. The LSE did not produce any toxic effect on the relative organ weight of the lungs, liver, heart, spleen, stomach and kidney of the rats. These findings, therefore, stand LSE in a good stead for development as a safe therapeutic agent for human ailments, where found to be potent.

\section{Acknowledgment}

The authors acknowledge the facilities made available by the staff of the Departments of Biochemistry and Microbiology, Federal University of Technology, Minna, Nigeria.

\section{References}

1. Odeghe O, Uwakwe AA, Monago C.C. Some biochemical and haematological studies on the methanolic extract of Anthocleista grandiflora stem bark. International Journal of Applied Science and Technology.2012; 2: 58-65. Ref.: https://goo.gl/rAXKCC

2. Probst R, Lim J, Bird D, Pole G, Sato A, et al. Gender Differences in Blood Volume of Conscious Sprague-Dawley Rats. J Am Assoc Lab Anim Sci. 2006; 45: 49-52. Ref.: https://goo.gl/4diu41

3. VanMeter K, Hubert R. Microbiology for the healthcare professional (2nd Ed.). St Loius, MO: Elsevier 2015; 263-270. Ref.: https://goo.gl/ykJvYa

4. Whitaker I.S, Rao J, Izadi D, Batter P.E. Historical Article: Hirudo medicinalis ancient origins of, and treads in the use of medicinal leeches throughout history. British Journal of Oral Maxillofac Surgery. 2004; 42: 133-137. Ref.: https://goo.gl/Wq2V38

5. Srivastava A, Sharma R. A brief review on application of leech therapy. Arch Apll Sci Res. 2010; 2 : 271-274. Ref.: https://goo.gl/YZdnmq

6. Porshinsky B.S, Saha S, Grossman M.D, Beeryl P.R, Stawicki S.P. Clinical uses of the medicinal leech; a practical review. J Postgrad Med. 2011; 57: 65-71. Ref.: https://goo.gl/827iCk

7. Abdualkader $\mathrm{M}$, Ghawi A, Alaama M, Awang M, Merzouk A. Leech therapeutic applications. Indian J Pharm Sci. 2013; 75: 127-137. Ref.: https://goo.gl/3yWhsz

8. National Institute of Environmental Health Sciences - NIEHS (1985). "Respect for life".

9. Odunlade A, Taiwo I, Arojojoye 0, Lawal T. Hepatoxicity of Aqueous Leaf Extract of Bridelia ferruginea on the Liver of Albino Rats. Journal of Natural Science Research. 2015; 5: 57-64. Ref.: https://goo.gl/Z44dDK

10. Aniagu S, Nwinyi C, Akumka D, Ajoku G, Izebe K, et al. Toxicological studies in Rats Fed Nature Cure Bitters. Afr J Biotechnol. 2005; 4: 72-78. Ref.: https://goo.gl/KDLB5m

11. Shittu O, Lawal B, Blessing U, Haruna G, Abubakar A, et al. Alteration in Biochemical Indices Following Chronic Administration of Methanolic Extract of Nigeria Bee Propolis in Wister Rats. Asian Pacific journal of tropical disease. 2015; 5: 654-657. Ref.: https://goo.gl/RA6ptp

12. OECD. The OECD guideline for testing of chemical. The organization of Economic co-operation development. 2001; 1-14. Ref.: https://goo.gl/y6erBL

13. Renu S, Badri P. Screening of antibacterial activity of Hydroalcoholic extract of Cynodon dactylon. International Journal of Research in Ayurveda and Pharmacy. 2012; 3: 827-829. Ref.: https://goo.gl/rnAj9g

14. Kabiru Y, Okogun J, Gbodi T, Makun H, Obgadoyi E. Subchronic Toxicity Studies of Methanolic Extract of Eucalyptus camaldulensis (Leaf) In Wister Rats. Iosr Journal of Pharmacy. 2013; 3: 38-45. Ref.: https://goo.gl/FH6tXp

15. Atsafack S, Kuiate J, Mouokeu R, Koanga M, Tchinda A, et al. Toxicological studies of stem bark extract from Schefflera barteri Harms (Araliaceae). BMC Complement Alternative Medicine. 2015; 7 : 44. Ref.: https://goo.gl/oWsiGF

16. Sireatawong N, Lertprasertsuke U, Scrisawat S. Acute ans sub-chronic toxicity study of the water extract from Tiliacora trianora (Colebr.) Diets in rats. Songklankarin Journal of Science and Technology. 2008; 30: 729-737. Ref.: https://goo.gl/Zj8uB2 
17. Ezeja M, Anaga A, Asuzu, I. Acute and sub-chronic toxicity profile of methanol leaf extract of Gouania longipetala in rats. Journal of Ethnopharmacology. 2014; 151: 1155-1164. Ref.: https://goo.gl/ttv1Hr

18. Sellers R, Morton D, Michael B, Roome N, Johnson J, et al. Society of Toxicologic Pathology Position Paper: Organ Weight Recommendations for Toxicologic Studies. Toxicologic Pathology. 2007; 35: 751-755. Ref.: https://goo.gl/BuqbHf

19. Bailey S, Zidell R, Perry R. Relationships Between Organ Weight and Body/Brain Weight in the Rat: What Is The Best Analytical Endpoint? Toxicologic Pathology. 2004; 32: 448-466. Ref.: https://goo.gl/CPxH1R

20. Albert $D$, Telephone $B$, Jacques $Y$. Acute and subchronic oral toxicity assessment of the aqueous extract from the stem bark of Erythrina senegalensis DC (Fabaceae) in rodents. Journal of Ethnopharmacy. 2011; 134: 697-702. Ref.: https://goo.gl/PYkNpU

21. Enechi O, Ozougwu V. Effects of ethanol extract of Mucuna pruriens leaves on the lipid profile and serum electrolytes of rats. Journal of Pharmacy and Biological Sciences. 2014; 9: 18-23. Ref.: https://goo.gl/wHqjfr

22. Olatunji I, Adebayo $\mathrm{J}$, Oguntoye $\mathrm{O}$, Olatunde $\mathrm{N}$, Olatunji $\mathrm{V}$, et al. Effects of aqueous extracts of petals of red and green Hibiscus sabdariffa on plasma lipids and haematological variables in rats. Pharmaceutical Biology. 2005; 43: 471-474. Ref.: https://goo.gl/e6BGUD

23. EL-Demerdash F. Antioxidant effect of vitamin $E$ and selenium on lipid peroxidation, enzyme activities and biochemical parameters in rats exposed to aluminium. Journal of Trace Elements and Medical Biology. 2004; 18: 113-122. Ref.: https://goo.gl/9Uyg6U

24. Mbajiorgu E, Air T, Volk W, Albert M, Debusho L. Haematological Profile of Male Rats Treated with Ethanol and/or Chloroquine and fed Normal or Low Protein Diet. The Internet Journal of Hematology. 2006; 3: 1-11.

25. Adebayo J, Adesokan A, Olatunji L, Buoro D, Soladoye A. Effect of ethanolic extract of Bougainvillea spectabilis leaves on haematological and serum lipid variables in rats. Biochemistry. 2005; 17: 4550. Ref.: https://goo.gl/i7WZmZ

26. Sani, D, Sanni S, Sandabe U, Ngulde S. Effect of intake of aqueous stem extract of Anisopus manni on haematilogical parameters in rats. International Journal of Applied Research in Natural products. 2009; 2: 22-28. Ref.: https://goo.gl/GQZdUR 